PROCEEDINGS OF THE

FIFTEENTH INTERNATIONAL

MACHINE TOOL DESIGN AND RESEARCH

CONFERENCE 
PROCEEDINGS OF THE

\title{
FIFTEENTH INTERNATIONAL MACHINE TOOL DESIGN AND RESEARCH CONFERENCE
}

\author{
held in Birmingham \\ 18-20 September 1974 \\ Edited by \\ S. A. TOBIAS \\ Chance Professor and Head of Department \\ Department of Mechanical Engineering \\ University of Birmingham \\ and \\ F. KOENIGSBERGER \\ Professor of Machine Tool Engineering \\ University of Manchester Institute of Science and Technology
}


All rights reserved. No part of this

publication may be reproduced or transmitted,

in any form or by any means, without permission.

First published 1975 by

THE MACMILLAN PRESS LTD

London and Basingstoke

Associated companies in New York

Dublin Melbourne Johannesburg and Madras

SBN 333150570

ISBN 978-1-349-01988-5 ISBN 978-1-349-01986-1 (eBook)

DOI $10.1007 / 978-1-349-01986-1$

(c) The Macmillan Press Limited 1975

Softcover reprint of the hardcover 1st edition 1975

Published in the U.S.A.

by Halsted Press, a Division

of John Wiley \& Sons, Inc. New York

Library of Congress Catalog Card No: 63-19240

ISBN 978-0-470-87532-2

Set by William Clowes and Sons Ltd., London, Colchester and Beccles 


\section{CONTENTS}

OPENING SESSION

Opening address. J. W. ATWELL

\section{GROUP TECHNOLOGY AND CELLULAR MANUFACTURE}

Group technology developments and modes of application. W. EVERSHEIM and M. MIESE

Total company appraisal for group technology. K. RATHMILL, P. BRUNN and R. LEONARD

Batch size selection for group technology. K. RATHMILL, P. BRUNN and R. LEONARD

The interaction of NC and GT. F. W. CRAVEN

Some organizational aspects of cellular manufacture based on computer simulation. $\mathrm{D}$. ATHERSMITH and J. R. CROOKALL

\section{CNC AND DNC}

BCLCNC-a computer numerical control system. N. AKGERMAN

Closed loop positioning control for a DNC-milling machine. A. M. LOSS and J. FRISCH

Adaptive control constraint and automatic cut distribution system for turning operations. E. GIESEKE

The improvement in accuracy of high precision machine tools by means of adaptive control. I. WASIUKIEWICZ

The machining-centre concept; an analysis of a tool-changing manufacturing system. J. R. CROOKALL and A. T. M. JAMIL

The NEL/MTIRA technological forecast for the computer control of machine tools. B. DAVIES, J. W. BRUCE and A. E. De BARR

\section{CAD AND CAM}

Combination of CAD and CAM in machine tool manufacture. P. STÖCKMANN and G. WÖLLNER

The application of CAD techniques to machine tool component design, production and manufacture. A. JEBB, C. B. BESANT and R. C. EDNEY

A new generalized concept of computer aided production. J. FERENCZY and J. LEHOTZKY

Computer-aided design of axisymmetric hot forging dies. S. K. BISWAS and W. A. KNIGHT

Graph theory applied to computer aided plant layout. A. S. CARRIE

\section{MACHINE TOOL ELEMENTS}

An analysis of a new type of high precision multiwedge clearanceless bearing for grinding wheel spindles. G. K. ARORA and T. S. R. MURTHY AVRAMOVIC and P. FORT and R. M. BUENO

\section{METAL CUTTING}

Coolants and cutting tool temperatures. E. F. SMART and E. M. TRENT

Tool wear or tool design (a case study). R. A. ETHERIDGE and A. J. A. SCOTT
Ultra-high-speed machining: notes on metal cutting at speeds up to $7300 \mathrm{ft} / \mathrm{s}$. G. ARNDT

On line measurement of bending and torque in milling. R. BEDINI and P. C. PINOTTI

Power hacksawing. P. J. THOMPSON and M. SARWAR

Optimization of drill geometry for orthopaedic surgery. G. H. FARNWORTH and J. A. BURTON

\section{MACHINE TOOL DYNAMICS}

The dynamic characteristics of epoxy resin bonded machine tool structures. $\mathrm{M}$. I. 
On-line identification of machine tool receptances from cutting experiments. $N$. H. HANNA and A. W. KWIATKOWSKI

Influence of lathe tool wear on the vibrations sustained in cutting. P. MARTIN, B. MUTEL and J.P. DRAPIER

Investigation of parametric instability in milling simulated by screw chasing operation. $G$. DROUBI and M. M. SADEK

Elastic wave transmission and reflection in long uniform bars due to the end impact of a rigid mass. W. JOHNSON

\section{NOISE AND ITS REDUCTION}

Noise generation from an impact forming machine structure. A. E. M. OSMAN, W. A. KNIGHT and M. M. SADEK

Noise reduction in a HERF cropping machine. G. DROUBI, M. M. SADEK and S. A. TOBIAS

The effect of blade wear on noise levels of power hacksaws. G. J. McNULTY

\section{GRINDING AND SURFACE TOPOGRAPHY}

Optimization of a grinding process and criteria for wheel life. G. TRMAL and H. KALISZER

The collection of data for the assessment of a grinding wheel dressing treatment. E. J. PATTINSON and J. LYON

Chattering phenomena as the criterion of redress life of grinding wheel: a study on the establishment of optimum operational condition in precision grinding of hardened steel. H. MAKINO

Finishing and running-in of plain bearings, with an economic appraisal. G. TRMAL, H. KALISZER and G. W. ROWE

In-process indication of surface roughness using a fibre-optics transducer. D. SPURGEON and R. A. C. SLATER

Performance analysis of the stylus technique of surface roughness assessment: a random field approach. J. B. AGULLO and J. PAGES-FITA

\section{EDM AND ECM}

Conditioning a diamond-grit cup-wheel for electrochemical grinding. M. M. SFANTSIKOPOULOS and C. F. NOBLE

Electro-discharge machined surfaces. J. R. CROOKALL and B. C. KHOR

Some effects of debris concentration on erosion and electrode wear in electro-discharge machining. J. R. CROOKALL and P. W. LEE

Investigation of the modulation of interface waves in explosive welding. S. R. REID and D. J. LANGDALE

Implosive welding of composite metal-foil cylinders. $H$. EL-SOBKY and T. Z . BLAZYNSKI

The cold drawing of implosively welded bi-metallic tubes. S. TOWNLEY and T. Z. BLAZYNSKI

\section{HOT FORMING}

Transverse deformation in section rolling and forging. G. W. ROWE, I. M. DESAI and H. S. SHIN

A study on plastic working of alloys in their mashy state. S. FUKUOKA and M. KIUCHI

Stress strain curves from the ring test. A. N. BRAMLEY and N. A. ABDUL

An elemental upper-bound technique for general use in forging analysis. R. P. McDERMOTT and A. N. BRAMLEY

Application of a modular approach to estimate load and energy in closed die forging. S. K. BISWAS and B. W. ROOKS

The elevated temperature extrusion of fluted sections in high-speed steels. C. E. N. STURGESS and T. A. DEAN

\section{DIE LIFE IN HOT FORMING}


The effect of die temperature on metal flow and die wear during high-speed hot forging. B. W. ROOKS

\section{ROLLING}

Ball rolling: a literature survey and some experimental results. N. R. CHITKARA, W. JOHNSON and J. R. S. UTTLEY

An experimental investigation into the S-mill rolling process. D. K. ROBERTSON and D. H. SANSOME

\section{DRAWING, TUBE AND SHEET FORMING}

A preliminary investigation of the die-less drawing of titanium and some steels. J. M. ALEXANDER and T. W. TURNER

A fundamental study on dieless drawing. H. SEKIGUCHI, K. KOBATAKE and K. OSAKADA

Theoretical study of the drawing of bi-metal rod and tube. H. T. CHIA and D. H. SANSOME

An oscillatory deep-drawing analogue. M. J. R. YOUNG and D. H. SANSOME

Rigid-plastic analysis of bore expanding and flange drawing with anisotropic sheet metals by the matrix method. S. H. LEE and S. KOBAYASHI

Tube inversion: a process for obtaining gross expansions in the diameter of thin-wall tubes. S. T. S. Al-HASSANI

\section{COLD FORMING, BLANKING AND CROPPING}

The strength of the material in cold formed parts. J. DATSKO

The development of a cold forming process on an automatic high-speed forming machine. T. SCAIFE, B. PARSONS and B. N. COLE

Forward cold extrusion of aluminium-estimation of the maximum extrusion force. L. E. FARMER and B. Z. PIROG

Rigid-plastic analysis of cold heading by the matrix method. S. N. SHAH and S. KOBAYASHI

Production of crankshafts by clamp shearing. T. NAKAGAWA and K. SHIOMORI

Analysis of stresses in bar cropping. V. G. WONG and M. K. DAS

\section{COMPACTION AND SINTER FORGING}

The dynamic compaction of aluminium and iron powder. D. RAYBOULD

The hot extrusion of metal powder preforms. M. NEGM and R. DAVIES

Plasticity of sintered iron-powder compacts. S. D. El WAKIL

The effect of presintering conditions on the cold forgeability of powder preforms. M. A. RIFAI

The production of extruded material from metal powders. T. SHEPPARD

Comparison between uniaxial and isostatic densified stainless-steel powder preforms forged in a closed die. H. ALTMANN

Powder compaction at very high pressures. P. N. TOMLINSON, R. L. HEWITT and R. D. VENTER

\section{GENERAL ASPECTS OF FORMING}

Strong composites based on all-metal systems. D. V. WILSON, W. T. ROBERTS, J. J. MOORE, R. F. STOKES and J. FARMER

Characteristic features in the hole flanging and piercing of thin and thick circular plates using conical and ogival punches. W. JOHNSON, N. R. CHITKARA and P. A. BEX

The influence of hydrostatic pressure on the plastic deformation of metallic materials. W. LORREK and O. PAWELSKI

The toughness of M2 high-speed steel. G. BERRY and M. J. KADHIM Al-TORNACHI

Analysis of large, natural strain increments using the Mohr's circle. J. WOLAK

Smooth hole wall piercing in the manufacture of precision mechanisms. R. JOHNSTON and K. SWIFT 